\title{
In vitro reconstitution of branched microtubule nucleation
}

Ammarah Tariq, Lucy Green, J Charles G. Jeynes, Christian Soeller and James G.

$$
\text { Wakefield }{ }^{\#}
$$

Living Systems Institute, University of Exeter, Stocker Road, Exeter, EX4 4QD, UK.

\#Contact: James G. Wakefield (j.g.wakefield@exeter.ac.uk) 


\section{Abstract}

1 Eukaryotic cell division requires the mitotic spindle, a microtubule (MT)-based

2 structure which accurately aligns and segregates duplicated chromosomes. The 3 dynamics of spindle formation are determined primarily by correctly localising the MT

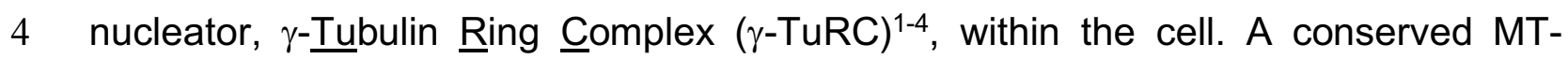
5 associated protein complex, Augmin, recruits $\gamma$-TuRC to pre-existing spindle MTs, 6 amplifying their number, in an essential cellular phenomenon termed "branched" MT

7 nucleation ${ }^{5-9}$. Here, we purify endogenous, GFP-tagged Augmin and $\gamma$-TuRC from

8 Drosophila embryos to near homogeneity using a novel one-step affinity technique.

9 We demonstrate that, in vitro, while Augmin alone does not affect Tubulin 10 polymerisation dynamics, it stimulates $\gamma$-TuRC-dependent MT nucleation in a cell

11 cycle-dependent manner. We also assemble and visualise the MT-Augmin- $\gamma$-TuRC-

12 MT junction using light microscopy. Our work therefore conclusively reconstitutes

13 branched MT nucleation. It also provides a powerful synthetic approach with which to

14 investigate the emergence of cellular phenomena, such as mitotic spindle formation,

15 from component parts.

20 Branched MT nucleation, and its dependence on Augmin and $\gamma$-TuRC, generates the

21 bulk of MTs required for both meiotic and mitotic spindle formation ${ }^{10,11}$ and has been

22 visualised in vivo in Drosophila, Xenopus, plants, and humans ${ }^{5,6,9-14}$. However, 
bioRxiv preprint doi: https://doi.org/10.1101/700419; this version posted July 11, 2019. The copyright holder for this preprint (which was not certified by peer review) is the author/funder, who has granted bioRxiv a license to display the preprint in perpetuity. It is made available under aCC-BY 4.0 International license.

Branched MT nucleation

Tariq et al.,

24 by methodological constraints relating to purification of functional protein complexes ${ }^{15,16}$; Augmin is composed of 8 subunits, while the $\gamma$-TuRC is a $\sim 2 \mathrm{MD}$

26 protein complex containing multiple copies of at least 5 proteins, including 14

27 molecules of $\gamma$-Tubulin ${ }^{1-4,17}$. In vitro studies generally use proteins that have been

28 individually- or co-expressed and purified in heterologous systems ${ }^{18,19}$, where folding

29 and post translational modifications crucial to function may not occur. Although

30 purification of protein complexes from autogenous cells can be achieved using

31 affinity-based methods, non-specific binding of contaminating proteins and difficulties

32 in releasing purified proteins from affinity matrices are major problems.

33 We therefore developed an approach to allow the isolation of intact, functional

34 Augmin and $\gamma$-TuRC, to test the hypothesis that these two complexes are necessary and sufficient for branched MT nucleation. The approach is based on biotinylated, amine-reactive thiol- or photo-cleavable linkers, Sulfo-NHS-SS-Biotin and PC-BiotinNHS (Figure 1a). Stepwise incubation of the $\sim 12 \mathrm{kD}$ camelid anti-GFP nanobody, 38 GFP-TRAP, with either of these linkers resulted in covalent linkage, while subsequent incubation with a Streptavidin Agarose matrix led to stable tri-partite reagents - GFP-TRAP-Sulfo beads and GFP-TRAP-PC beads; where GFP-TRAP is

41 immobilised, but cleavable through the addition of DTT or exposure to UV light, 42 respectively (Figure 1a).

43 To test these reagents, beads were incubated with bacterially expressed and purified 44 6xHis-GFP, and extensively washed. Individual beads fluoresced with varying 45 intensity and, upon brief exposure to $50 \mathrm{mM}$ DTT or UV light, fluorescence 46 decreased, concomitant with an increase in the surrounding medium (Figure 1b; 47 Supplementary Figure 1a,b). Western blot analysis confirmed $>90 \%$ and $\sim 60 \%$ of 
bioRxiv preprint doi: https://doi.org/10.1101/700419; this version posted July 11, 2019. The copyright holder for this preprint (which was not certified by peer review) is the author/funder, who has granted bioRxiv a license to display the preprint in perpetuity. It is made available under aCC-BY 4.0 International license.

Branched MT nucleation

Tariq et al.,

48 GFP was released from GFP-TRAP-Sulfo and GFP-TRAP-PC beads, respectively,

49 following cleavage (Figure 1c; Supplementary Figure 1c).

50 We next sought to determine whether this "cleavable Affinity Purification" (cl-AP) could be used to isolate Augmin and $\gamma$-TuRC. We have previously shown that

Drosophila Augmin can be purified from extracts of early embryos expressing a GFP-tagged variant of the Msd1 subunit ${ }^{20}$. Drosophila embryos have also been used to purify the $\gamma$-TuRC 2,17 , and flies expressing $\gamma$-Tubulin-GFP are available ${ }^{21}$. As branched MT nucleation is essential during mitosis, we used embryos arrested in a metaphase-like state through incubation with the proteasomal inhibitor, MG132 ${ }^{22}$. Both Msd1-GFP and $\gamma$-Tubulin-GFP were efficiently immobilised on GFP-TRAP-Sulfo or GFP-TRAP-PC beads and western blotting confirmed that, upon cleaving, Msd1GFP and $\gamma$-Tubulin-GFP were concentrated in the eluate, with other subunits of the complexes co-eluting (Figure 1c; Supplementary Figure 1d). To test the purity of the complexes, we subjected MG132-treated control, Msd1-GFP or $\gamma$-Tubulin-GFP embryo extracts to GFP-TRAP-Sulfo cl-AP followed by gel electrophoresis and SYPRO-ruby staining of eluates (Figure 1d). Bands corresponding to each subunit of both Augmin and $\gamma$-TuRC were identified at intensities expected for the known stoichiometric relationships between subunits ${ }^{17}$. One additional set of low intensity bands was seen in all eluates, at $\sim 45 \mathrm{kD}$; almost certainly corresponding to yolk proteins - the most abundant proteins in Drosophila early embryos ${ }^{23}$.

68 Both $\gamma$-TuRC and Augmin bind MTs in co-sedimentation assays ${ }^{5,24-25}$. We therefore incubated mitotic Augmin-GFP or $\gamma$-TuRC-GFP with pure Tubulin, in the presence of GTP and taxol to promote MT polymerisation, sedimenting through a glycerol cushion to separate MTs and MT associated proteins from soluble Tubulin and non-

72 MT binding proteins (Figure 1e; Supplementary Figure 1e). As expected, both 
bioRxiv preprint doi: https://doi.org/10.1101/700419; this version posted July 11, 2019. The copyright holder for this preprint (which was not certified by peer review) is the author/funder, who has granted bioRxiv a license to display the preprint in perpetuity. It is made available under aCC-BY 4.0 International license.

Branched MT nucleation

Tariq et al.,

73 Msd1-GFP and $\gamma$-Tubulin-GFP co-sedimented with MTs, demonstrating purified

74 Augmin and $\gamma$-TuRC maintain at least some of their cellular properties.

75 To assess the effects of pure Augmin and $\gamma$-TuRC on MT nucleation and polymerisation, we used a highly-reproducible quantitative assay, where incorporation of a dye into MTs as they polymerise is measured as a change in fluorescence ${ }^{26}$ (Cytoskeleton Inc.). Incubation of Tubulin in the presence of GTP and glycerol at $37^{\circ} \mathrm{C}$ resulted in its polymerisation over $\sim 1$ hour, with sigmoidal dynamics corresponding to lag, nucleation, polymerisation and plateau phases (Figure 2a). The time at which $50 \%$ of polymerisation was achieved $(x 50)$ was $31.5 \mathrm{mins}(+/-0.5$ mins) (Figure 2b). Addition of $\gamma$-TuRC-GFP stimulated MT nucleation, causing a shift in the polymerisation curve and a reduction in the $x 50$ to $16.5 \mathrm{mins}$ (+/- $1.2 \mathrm{~min}$ ) (Figure 2a,b), confirming its functionality. In contrast, addition of Augmin-GFP had no significant effect on the shape of the polymerisation curve or the x50 (32.5 mins (+/-1.5 min) (Figure 2a,b). Therefore, although Augmin-GFP binds MTs it does not,

87 in isolation, change MT nucleation/polymerisation dynamics. However, addition of Augmin-GFP dramatically enhanced $\gamma$-TuRC-dependent nucleation of MTs, further 89 reducing the $\times 50$ to $9.5 \mathrm{~min}(+/-0.45 \mathrm{~min})$ (Figure $\mathbf{2 a}, \mathbf{b})$. This effect was specific for 90 the physical interaction between Augmin and $\gamma$-TuRC, as addition of bacterially expressed and purified truncated Augmin subunits, Dgt3, Dgt5 and Dgt6, which we previously demonstrated interact directly with $\gamma$-TuRC ${ }^{20}$, resulted in nucleation/polymerisation curves indistinguishable to $\gamma$-TuRC alone (Supplementary 94 Figure S2a-c). Thus, pure Augmin does, indeed, augment $\gamma$-TuRC-dependent MT 95 nucleation in vitro.

96 Importantly, this phenomenon was dependent on whether the complexes were 97 isolated from mitotically arrested (MG132) or untreated, mainly interphase embryos 
bioRxiv preprint doi: https://doi.org/10.1101/700419; this version posted July 11, 2019. The copyright holder for this preprint (which was not certified by peer review) is the author/funder, who has granted bioRxiv a license to display the preprint in perpetuity. It is made available under aCC-BY 4.0 International license.

Branched MT nucleation

Tariq et al.,

98 (cycling). $\gamma$-TuRC purified from cycling embryos was a less efficient nucleator than its

99 mitotic counterpart (Figure 2c; Supplementary Figure S3), while cycling Augmin, like

100 mitotic Augmin, showed no independent activity. However, when incubated together,

101 either mitotic $\gamma$-TuRC and cycling Augmin or cycling $\gamma$-TuRC and mitotic Augmin were

102 able to enhance MT nucleation to the same extent as both mitotic complexes

103 (Figure 2c; Supplementary Figure S3). As cell cycle dependent changes in protein

104 function are determined mostly by post-translational modifications (PTMs), this

105 observation suggests that PTMs of both Augmin and $\gamma$-Tubulin are crucial in vivo.

106 To characterise the morphology of MTs generated in the presence of pure Augmin

107 and $\gamma$-TuRC, we took samples from the in vitro assays at $\mathrm{t}=15$ minutes, fixing and

108 imaging them via fluorescence microscopy. Control samples, or those containing

109 pure Augmin, showed only very few, short MTs per field of view while, as expected,

$110 \gamma$-TuRC-containing samples possessed many individual MTs (Figure 3a). In contrast,

111 the MT population nucleated at $\mathrm{t}=15$ simulataneously with $\gamma$-TuRC and Augmin

112 showed a high density of MTs, with extensive MT bundling and nesting, rather than

113 individual MTs (Figure 3a). Moreover, consistent with the observation that, in vivo,

114 Augmin is required for $\gamma$-Tubulin localisation to the mitotic spindle, pure Augmin was

115 able to recruit pure $\gamma$-TuRC to MTs in vitro, co-localising along the length of MTs in

116 distinct punctae (Supplementary Figure S4).

117 Finally, we sought to conclusively reconstitute and visualise the branching MT-

118 Augmin- $\gamma$-TuRC-MT junction. To overcome the complex morphology of MTs resulting

119 from the nucleation assay, we generated populations of taxol-stabilised fluorescent

120 MTs in the presence or absence of individual protein complexes, subsequently co-

121 incubating them. Co-incubation of HiLyte Fluor 488-MTs ( $\left.{ }^{488} \mathrm{MTs}\right)$ with Rhodamine-

122 MTs (RhodMTs) resulted in independent populations of MTs. Occasional overlaps and 
bioRxiv preprint doi: https://doi.org/10.1101/700419; this version posted July 11, 2019. The copyright holder for this preprint (which was not certified by peer review) is the author/funder, who has granted bioRxiv a license to display the preprint in perpetuity. It is made available under aCC-BY 4.0 International license.

Branched MT nucleation

Tariq et al.,

apparent branching were observed, but at a frequency consistent with random

124 placement of MTs on coverslips (Figure $3 \mathbf{b}, \mathbf{d}$ ). Similar results were obtained with

125 fluorescent MTs incubated with either Augmin or $\gamma$-TuRC (Figure 3b,d). However,

126 when ${ }^{488}$ MTs incubated with Augmin were added together with RhodMTs incubated

127 with $\gamma$-TuRC, $\sim 60 \%$ of $\gamma$-TuRC-containing RhodMTs terminated precisely at an

128 Augmin-containing ${ }^{488} \mathrm{MT}$ (Figure $3 \mathbf{b}-\mathbf{d}$ ). Although the polarity and angles of the

129 RhodMTs branches in relation to the "mother" ${ }^{488}$ MTs varied far more widely than seen

130 in vivo, presumably due to how the MTs settled on the coverslip during preparation,

131 we found a bias in the angle, similar to that seen in living Drosophila ${ }^{16}$ (Figure $3 \mathbf{e}$ ).

132 To unequivocally demonstrate the polarity of the MTs, we formed these junctions in

133 the presence of pre-stabilised HiLyte 647-labelled GMPCPP MT seeds, to

134 additionally distinguish the slower-growing MT minus ends. As expected, the polarity

135 of the interaction between $\gamma$-TuRC-RhodMTs and Augmin- ${ }^{488}$ MTs was specific; with

136 only the minus ends of $\gamma$-TuRC- ${ }^{\text {RhodMTs }}$ precisely terminating at the Augmin- ${ }^{488} \mathrm{MTs}$

137 lateral surfaces (Figure 3f). Moreover, the formation of junctions on Augmin-

138 containing ${ }^{488} \mathrm{MTs}$ was length independent - branches were equally distributed at the

139 very distal MT tips, throughout their length and on the GMPCPP seed itself (Figure

$140 \quad 3 f, g)$.

141

142 Our work confirms a long-standing hypothesis, first articulated to explain the loss of

$143 \gamma$-Tubulin on the mitotic spindle when the expression of Augmin subunits is

144 reduced ${ }^{27}$. It demonstrates conclusively that Augmin directly recruits $\gamma$-TuRC to MTs

145 and that these two protein complexes are sufficient for the phenomenon of branched

146 MT nucleation. It does not, however, exclude the possibility that in vivo, at least in

147 some biological systems, other proteins tune branched MT nucleation to the 
bioRxiv preprint doi: https://doi org/10.1101/700419; this version posted July 11, 2019. The copyright holder for this preprint (which was not certified by peer review) is the author/funder, who has granted bioRxiv a license to display the preprint in perpetuity. It is made available under aCC-BY 4.0 International license.

Branched MT nucleation

Tariq et al.,

148 individual needs of the cell. For example, a clear role has been reported for the MT

149 associated protein, TPX2, in stimulating Augmin-dependent branched MT nucleation

150 in Xenopus meiotic extracts ${ }^{9,28}$. However, in support of our conclusions, Drosophila

151 TPX2 has recently been shown to be dispensible for the phenomenon in vivo ${ }^{29}$. Our

152 experiments also highlight the intriguing possibility that, in some cells, Augmin might

153 recruit pre-existing $\gamma$-TuRC-containing MTs, nucleated elsewhere in the cell,

154 anchoring then to specific sites and increasing local MT density.

156 The generation of stable MT-Augmin- $\gamma$-TuRC-MT junctions using the methodologies

157 pioneered here, also provide a route to finally defining the molecular detail of MT

158 branching at the ultrastructural level. More broadly, cleavable affinity purification

159 provides the basis to generate more complex, but molecularly defined, mixes of pure

160 proteins, complete with in vivo PTMs, in order to reconstitute higher-order aspects of

161 spindle formation. Indeed, by isolating and combining purified proteins and protein

162 complexes from any biological system of interest, cl-AP overcomes the limitations of

163 traditional "bottom-up" approaches, allowing exploration of the level of biological

164 organisation between individual protein and biological process - the level at which

165 emergence of cellular phenomena often occurs.

Methods

170 Drosophila husbandry and embryo collection

171 Flies were kept on standard medium and grown according to standard laboratory

172 procedures. w1118 or Oregon R (OrR) strains (Bloomington Stock Center) were 
bioRxiv preprint doi: https://doi.org/10.1101/700419; this version posted July 11, 2019. The copyright holder for this preprint (which was not certified by peer review) is the author/funder, who has granted bioRxiv a license to display the preprint in perpetuity. It is made available under aCC-BY 4.0 International license.

Branched MT nucleation

Tariq et al.,

utilized as a wild-type controls. Transgenic flies used were: pUAS-Msd1-GFP;

174 maternal- $\alpha-T u b u l i n-G a l 4^{26}$ and $p N c d(\gamma-T u b 37 C-G F P)$, a gift from Sharyn Endow ${ }^{22}$.

175 0-3-hour old embryos were collected from apple juice/Agar plates, dechorionated

176 using bleach, washed, flash frozen in liquid nitrogen and stored at $-80^{\circ} \mathrm{C}$. For

177 MG132 treatment, embryos were incubated in a solution containing $66.5 \%$ PBS

178 (Melford), 33.2\% heptane (Sigma) and 0.3\% MG132 (Sigma) for 20 mins, prior to

179 rinsing and flash freezing as above. Each embryo collection resulted in $0.05-0.1 \mathrm{~g}$ of

180 frozen embryos, different batches of which were combined for each biochemical

181 assay/purification. Routinely, batches of MG132-treated embryos were fixed and stained to visualise chromosomes and MTs, to verify their mitotic arrest.

184 Preparation of GFP-TRAP-PC and GFP-TRAP-Sulfo beads

185 To prepare GFP-TRAP-Sulfo beads, $200 \mu \mathrm{L}$ of GFP-TRAP® $(1 \mathrm{mg} / \mathrm{mL})$ (Chromotek)

186 in PBS was incubated with $86.1 \mu$ of Sulfo-NHS-SS-Biotin (sulfosuccinimidyl-

187 20(biotinamido)ethyl-1,3-dithiopropionate) (8mM) (Thermo Scientific) for 2 hrs at $4^{\circ} \mathrm{C}$.

188 Unreacted linker was removed by desalting. $40 \mu \mathrm{L}$ of High Capacity Streptavidin

189 Agarose Resin (Pierce) was washed 3 times for 5 mins in PBS and incubated with

190 the GFP-TRAP-SS-Biotin product for $1 \mathrm{hr}$ at $4^{\circ} \mathrm{C}$ with gentle rotation. The beads

191 were washed 3 times for 5 mins in BRB80 + 0.1\% IGEPAL $®$, the volume of BRB80

192 was reduced to $40 \mu \mathrm{L}$ (to maintain a $50 \%$ bead slurry) and beads stored at $4^{\circ} \mathrm{C}$ for

193 use. A similar protocol was used to generate GFP-TRAP-PC-Biotin-NHS beads, but

194 using $50 \mu \mathrm{L}$ of GFP-TRAP®, incubated with $1.45 \mu \mathrm{L}$ of PC-Biotin-NHS (50mM)

195 (Ambergen) for 40 minutes at RT with gentle rotation and $400 \mu \mathrm{L}$ of standard

196 Streptavidin-Agarose bead slurry (Sigma Aldrich). Over the course of the project,

197 different conditions were tried in an attempt to increase the photo-cleaving of GFP, 
bioRxiv preprint doi: https://doi.org/10.1101/700419; this version posted July 11, 2019. The copyright holder for this preprint (which was not certified by peer review) is the author/funder, who has granted bioRxiv a license to display the preprint in perpetuity. It is made available under aCC-BY 4.0 International license.

Branched MT nucleation

Tariq et al.,

198 GFP-Augmin and GFP- $\gamma$-TuRC from the GFP-TRAP-PC beads. We were unable to

199 consistently reach cleaving efficiencies of greater than $60 \%$. In contrast, cleavage of

200 proteins and complexes from GFP-TRAP-Sulfo-beads reproducibly gave efficiencies

201 of $>90 \%(n=>10)$.

202

203 Cleavable Affinity Purification

204 Drosophila embryo High Speed Supernatant (HSS) was prepared using batches of

205 frozen $0-3 \mathrm{hr}$ embryos. Embryos were dounce homogenised in BRB80 $+0.1 \%$

206 IGEPAL + 1mM PMSF (Sigma), PhosSTOP phosphotase inhibitors and cOmplete,

207 Mini, EDTA free protease inhibitors (Roche) at a ratio of $100 \mathrm{mg}$ embryos to $200 \mu \mathrm{L}$

208 buffer. Extracts were clarified through centrifugation at: 17,000 g for $10 \mathrm{~min}, 100,000$

$209 \mathrm{~g}$ for $10 \mathrm{~min}$, and $100,000 \mathrm{~g}$ for a further $30 \mathrm{~min}$. 6xHis-GFP was purified from

210 bacteria expressing pQE80-His-GFP, using standard protocols and HisPur ${ }^{\mathrm{TM}}$ Cobalt

211 Resin (Thermo Scientific), and dialysed into BRB80 + 0.1\% IGEPAL + 1mM PMSF.

212

213 Typically, HSS from 200 mg embryos or 6xHis-GFP (100ng) were incubated

214 overnight at $4^{\circ} \mathrm{C}$ with $20 \mu \mathrm{L}$ of either GFP-TRAP-PC or GFP-TRAP-Sulfo beads. For

215 SYPRO-Ruby staining (see below) HSS from $1 \mathrm{~g}$ of embryos expressing either

216 Msd1-GFP or $\gamma$-Tubulin-GFP were used, incubated with $50 \mu \mathrm{L}$ of GFP-TRAP-Sulfo

217 beads. Beads were centrifuged at $2500 \mathrm{~g}$ for 2 mins and the depleted supernatant

218 removed and discarded, or used for Western blotting. For cleaving of Sulfo-beads,

219 beads were washed 4 times for 5 mins in BRB80 + 0.1\% IGEPAL $®$, resuspended in

$22025 \mu \mathrm{L}$ of BRB80 $+0.1 \%$ IGEPAL $®$, prior to addition of $25 \mu \mathrm{L}$ of $100 \mathrm{mM}$ DTT in

221 BRB80 0.1\% IGEPAL $®$ for 5 mins (50mM final concentration). For PC-beads, beads

222 were washed as above, then transferred to a microscope slide with a concave cavity 
bioRxiv preprint doi: https://doi.org/10.1101/700419; this version posted July 11, 2019. The copyright holder for this preprint (which was not certified by peer review) is the author/funder, who has granted bioRxiv a license to display the preprint in perpetuity. It is made available under aCC-BY 4.0 International license.

Branched MT nucleation

Tariq et al.,

223 with $25 \mu \mathrm{L}$ of BRB80 $0.1 \%$ IGEPAL $®$. The slide was placed $10 \mathrm{~cm}$ below a UV lamp

224 (UVP XX-15L (Analytik Jena US)) and exposed for 30 second intervals with gentle

225 mixing between. Eluates were removed using a Gel-Saver II pipette tip (STARLAB).

226 Cleaved beads were washed 4 times for 5 minutes in BRB80 0.1\% IGEPAL®. After each purification, samples were taken for SDS-PAGE and Western blotting alongside known amounts of 6xHis-GFP, in order to quantify yield. cl-AP of $200 \mu \mathrm{g}$ of embryos using GFP-TRAP-Sulfo beads consistently yielded $\sim 400$ ng of Msd1-GFP and $\gamma$-Tubulin-GFP $(50 \mu$ at 8-9 $\mathrm{ng} / \mathrm{uL})(\mathrm{n}=6)$.

\section{SDS-PAGE and Western blot analysis.}

233 Protein samples were fractionated by sodium dodecyl sulfate (SDS)-polyacrylamide 234 gel electrophoresis (PAGE). SYPRO Ruby Staining (Invitrogen) of Augmin and $\gamma$ TuRC was undertaken according to manufacturer's instructions. For Western analysis, the proteins were blotted onto a nitrocellulose membrane and probed with anti-GFP (1:1000; Sigma-Aldrich and Roche), anti-dgt6 (1:500) (a gift from M. Gatti), or anti-Dgrip91 antibodies (1:1000) (a gift from X. Zheng). IRDye 800CW goat antirabbit (LI-COR) and IRDye 680RD goat anti-mouse (LI-COR) IgG polyclonal Abs were used as secondary detection antibodies. Fluorescence from blots was developed with the Odyssey CLx Imaging System (LI-COR) according to the manufacturer's instructions.

\section{$\underline{\text { In Vitro Microtubule Co-sedimentation Assay }}$}

245 Purified GFP, GFP-Augmin or GFP- $\gamma$-TuRC were pre-spun at 100,000 $\mathrm{g}$ for $15 \mathrm{~min}$ at 
bioRxiv preprint doi: https://doi.org/10.1101/700419; this version posted July 11, 2019. The copyright holder for this preprint (which was not certified by peer review) is the author/funder, who has granted bioRxiv a license to display the preprint in perpetuity. It is made available under aCC-BY 4.0 International license.

Branched MT nucleation

Tariq et al.,

248 Cytoskeleton Inc.), in a final volume of $50 \mu \mathrm{L}$. Taxol (Sigma) was added to $100 \mu \mathrm{M}$

249 and samples incubated for a further $10 \mathrm{~min}$ at $37^{\circ} \mathrm{C}$. A negative control for each

250 sample was run in parallel, where samples were incubated at $4^{\circ} \mathrm{C}$ and where GTB

251 replaced taxol. Samples were immediately spun through a $150 \mu \mathrm{L}$ cushion of BRB80

$25240 \%$ glycerol at $100,000 \mathrm{~g}$ for $45 \mathrm{~min}$ at $4^{\circ} \mathrm{C}$ in a TLA120.1 rotor (Beckmann

253 Coulter). The supernatant and pellet fractions were analysed by Western blotting,

254 probing with mouse anti-GFP (Roche) and anti- $\alpha$-Tubulin antibodies [DM1A]

255 (Sigma). Co-sedimentation assays were undertaken in triplicate, each with

256 independently purified Augmin or $\gamma$-TuRC. A representative western is shown.

$258 \quad$ MT polymerization assays

259 MT polymerization assays were performed using a fluorescence-based Tubulin

260 Polymerization kit (Cytoskeleton Inc, Denver CO, Cat. \# BK011P) following the

261 manufacturer's instructions. Briefly, $5 \mu \mathrm{L}(40 \mathrm{ng})$ of GFP, Augmin or $\gamma$-TuRC was

262 pipetted into wells within a 96-well microtiter plate, followed by $45 \mu \mathrm{L}$ of Tubulin

263 Reaction Mix. Tubulin polymerization was initiated by transferring the plate to a $37^{\circ} \mathrm{C}$

264 chamber of a plate reader. The polymerization dynamics of Tubulin were monitored

265 for 60 min at $37^{\circ} \mathrm{C}$ by measuring the change in fluorescence every 1 min using a

266 TECAN infinite 200pro fluorimeter, at excitation of $350 \mathrm{~nm}$ and emission of $440 \mathrm{~nm}$.

267 Assays to assess the effect of pure Augmin and $\gamma$-TuRC presented in Figure 2A are

268 the summation of 3 individual purifications of each protein complex, undertaken in

269 duplicate wells (6 data points). Assays to assess the difference in polymerization

270 between cycling and MG132 purified Augmin and $\gamma$-TuRC, presented in Figure 2C

271 are the summation of triplicate experiments. In vitro polymerization assays to assess

272 the difference in Augmin-dependent polymerization upon addition of competing 
bioRxiv preprint doi: https://doi.org/10.1101/700419; this version posted July 11, 2019. The copyright holder for this preprint (which was not certified by peer review) is the author/funder, who has granted bioRxiv a license to display the preprint in perpetuity. It is made available under aCC-BY 4.0 International license.

Branched MT nucleation

Tariq et al.,

273 truncated Augmin subunits (Supplementary Figure S2) are the summation of

274 triplicate experiments.

275

276 Generation of fluorescent MTs

277 Tubulin Polymerization assays were performed as described above, but with the 278 following modifications: Rhodamine- or HiLyte Fluor 488-tubulin was used

279 (Cytoskeleton, Inc., Denver, CO) at a 1:10 ratio with unlabelled porcine tubulin (final

280 tubulin concentration, $2 \mathrm{mg} / \mathrm{ml}$ ). At $\mathrm{t}=15 \mathrm{~min}$, samples of MTs were incubated with

281 glutaraldehyde (0.5\% final concentration) for 15 mins. Fixed MTs were spotted onto

282 glass coverslips precoated with mounting media (85\% glycerol; $2.5 \% \mathrm{~N}, \mathrm{~N}$ propyl283 gallate) and imaged.

284

285 To generate fluorescent, taxol stabilised MTs, Rhodamine- or HiLyte Fluor 488286 tubulin was polymerized as above, but in the absence of pure complexes, but in the 287 presence of taxol at a final concentration of $20 \mu \mathrm{M}$. After 7 mins, the taxol288 stabilized MTs were removed from the well and incubated with $5 \mu \mathrm{L}$ (40 ng) of 289 Augmin, $\gamma$-TuRC or buffer for $10 \mathrm{~min}$ at room temperature. Samples were then 290 layered over a $150 \mu \mathrm{L}$ cushion of $15 \%$ glycerol in BRB80 and centrifuged at 135,000 $291 \times \mathrm{g}$ for $10 \mathrm{mins}$ at $25^{\circ} \mathrm{C}$ in a TLA120.1 rotor (Beckmann Coulter). The MT pellets 292 were gently resuspended in $50 \mu \mathrm{L}$ of General Tubulin Buffer containing 1mM GTP 293 and $30 \%$ glycerol, combined as necessary as $1: 1$ mixtures and incubated for 10 min 294 at room temperature. The samples were fixed with glutaraldehyde $(0.5-2 \%$ final 295 concentration) and spotted onto glass coverslips as above. Images were taken from 296 randomly distributed fields of the coverslips using a Leica TCS SP8 confocal laser 
bioRxiv preprint doi: https://doi.org/10.1101/700419; this version posted July 11, 2019. The copyright holder for this preprint (which was not certified by peer review) is the author/funder, who has granted bioRxiv a license to display the preprint in perpetuity. It is made available under aCC-BY 4.0 International license.

Branched MT nucleation

Tariq et al.,

scanning microscope. Representative images from one of three independent

experiments are shown.

299

300 For experiments to visualise MT polarity, HiLyte 647-labelled GMPCPP MTs were

301 generated according to the manufacturer's instructions (Jena Biosciences). Seeds were added to the polymerisation reactions at a 1:10 ratio and processed as described above. Images were taken from randomly distributed fields of the coverslips using a Leica TCS SP8 confocal laser scanning microscope. Representative images from one of two independent experiments are shown.

\section{$\underline{\text { Imaging and Image analysis }}$}

308 Samples were imaged using an inverted Leica TCS SP8 confocal laser scanning

309 microscope using a HCOL APO CS2 63x, NA 1.4 oil immersion lens (Leica, Wetzlar,

310 Germany). Standard filter sets were used to visualize Rhodamine, HiLyte Fluor 488,

311 and HiLyte Fluor 647 fluorescence. Images were captured as TIFFs using Leica

312 Application Suite X (LAS X), opened in FIJI and levels adjusted to maximise the full

313 range of pixel intensities. To quantify the \% of ${ }^{488} \mathrm{MTs}$ with Rhod MT branches, 8 fields

314 of view of each sample were randomly captured. ${ }^{488} \mathrm{MTs}$ over $\sim 1 \mu \mathrm{M}$ length in each

315 field of view were totaled, alongside the number of RhodMTs whose fluorescence

316 terminated precisely at a HiLyte ${ }^{488} \mathrm{MT}$ lateral surface (between $243-339{ }^{488} \mathrm{MTs}$ per

317 sample condition). To quantify the position of the branchpoints relative to the minus

318 ends of MTs, the length of HiLyte ${ }^{647}$ GMPCPP-containing ${ }^{488} \mathrm{MTs}$ were measured

319 using the line tool in ImageJ. The position of the RhodMT branch from the minus end

320 of these MTs, was also measured. The two sets of variables were subjected to

321 Pearson correlation coefficent analysis using an on-line tool 
bioRxiv preprint doi: https://doi org/10.1101/700419; this version posted July 11, 2019. The copyright holder for this preprint (which was not certified by peer review) is the author/funder, who has granted bioRxiv a license to display the preprint in perpetuity. It is made available under aCC-BY 4.0 International license.

Branched MT nucleation

Tariq et al.,

322 (https://www.socscistatistics.com/tests/pearson/default2.aspx), providing the graph in

323 Supplementary Figure 3 . The Pearson correlation coefficient was $r=0.9962$ at a $p$

324 value of $<0.00001$

325

326 Statistical analysis of polymerisation curves

327 Polymerisation data sets were fitted using a sigmoidal function. This characterised

328 each data set in terms of the maximum \& minimum fluorescence, the $\mathrm{x}$ value (min) at

$32950 \%$ distance between maximum and minimum y fluorescence value (termed ' $x 50$ ')

330 and the slope. The mean $x 50$ value for the control samples $(n=6)$ was $x=31.99$

331 (minutes) and $y=2411$ (fluorescence a.u.). This value was used as a fix point to

332 compare all the data sets. A one-way ANOVA was performed to compare the four

333 variables (control, Augmin, $\gamma$-TuRC, and Augmin $+\gamma-T u R C$ ), with each variable having

334 six repeats. A post-hoc Tukey test showed that all variables were significantly

335 different from each other at $p=0.001$ apart from the control and Augmin, which were

336 not significantly different from each other. Similar analyses were undertaken for the

337 comparison of polymerisation datasets between complexes isolated from MG132

338 and cycling embryos, and the augmenting activity of Augmin in the presence of

339 truncated Dgt3, Dgt5 and Dgt6 proteins. All fitting and analyses were performed in

340 MATLAB (the code and data can be found at

341 www.github.com/charliejeynes/microtubles).

\section{Acknowledgements}

345 We thank Stephen Green and Mark Wood (Exeter, UK) for initial discussions about 346 photocleavable and other tags, and Mary Munson (Massachusetts, US) for 
bioRxiv preprint doi: https://doi.org/10.1101/700419; this version posted July 11, 2019. The copyright holder for this preprint (which was not certified by peer review) is the author/funder, who has granted bioRxiv a license to display the preprint in perpetuity. It is made available under aCC-BY 4.0 International license.

Branched MT nucleation

Tariq et al.,

highlighting the potential of thiol-cleavable tags for native complex purification, as

348 published by the Rout lab (Rockefeller, US) ${ }^{30}$. We thank Chromotek for the gift of

349 GFP-TRAP; Jack Chen, Dan Hayward and Chris Sullivan for initial attempts to

350 develop the cl-AP technique; Marwan Al-Maqtoofi who supervised a set of University

351 of Exeter Natural Sciences undergraduate students and the Carlota Palmer PhD

352 students in setting up the plate reader-based MT nucleation/polymerisation assays.

353 Finally, we thank Carolyn Moores (Birkbeck, UK), Iris Leuke and Thomas Surrey

354 (Crick Institute, UK) for discussions and advice, and Sabine Petry for sharing

355 unpublished data and critical reading of the manuscript. L.G. was supported by a

356 University of Exeter Proof of Concept Award, A.T. by a Carlota Palmer University of

357 Exeter PhD Studentship and J.C.G.J. by an Innovation Fellowship supported by the

358 Science and Technology Facilities Council (STFC), U.K.

360 Author contributions

361 J.G.W. designed the study. L.G. developed the GFP-TRAP-PC approach and undertook associated experiments. A.T. conducted all other experiments. J.C.G.J. analysed the polymerisation assay data. C.S. co-supervised A.T. co-designed and analysed the imaging experiments. J.G.W. and A.T. analysed all other data and wrote the manuscript.

\section{References}


bioRxiv preprint doi: $\mathrm{https}$ ://doi.org/10.1101/700419; this version posted July 11,2019 . The copyright holder for this preprint (which was not certified by peer review) is the author/funder, who has granted bioRxiv a license to display the preprint in perpetuity. It is made available under aCC-BY 4.0 International license.

Branched MT nucleation

Tariq et al.,

373

374

375

376

377

378

379

380

381

382

383

384

385

386

387

388

389

390

391

392

393

394

395

396

397

398

399

400

401

402

403

404

405

406

407

408

2. Moritz, M., Braunfeld, M. B., Sedat, J. W., Alberts, B. \& Agard, D. A. Microtubule nucleation by $\mathrm{y}$-tubulin-containing rings in the centrosome. Nature 378, 638-640 (1995).

3. Kollman, J. M., Merdes, A., Mourey, L. \& Agard, D. A. Microtubule nucleation by y-tubulin complexes. Nat Rev Mol Cell Biol. 12, 709-721 (2011).

4. Tovey, C. A. \& Conduit, P. T. Microtubule nucleation by $\mathrm{Y}$-tubulin complexes and beyond. Essays Biochem. 62, 765-780 (2018).

5. Goshima, G., Mayer, M., Zhang, N., Stuurman, N. \& Vale, R. D. Augmin: a protein complex required for centrosome-independent microtubule generation within the spindle. $J$ Cell Biol. 181, 421-429 (2008).

6. Uehara, R. et al. The augmin complex plays a critical role in spindle microtubule generation for mitotic progression and cytokinesis in human cells. Proc. Natl. Acad. Sci.106, 6998-7003 (2009).

7. Sánchez-Huertas C, Lüders J. The augmin connection in the geometry of microtubule networks. Curr Biol. 25, R294-9 (2015).

8. Prosser, S. L. \& Pelletier, L. Mitotic spindle assembly in animal cells: a fine balancing act. Nat Rev Mol Cell Biol. 18, 187-201 (2017).

9. Petry, S., Groen, A. C., Ishihara, K., Mitchison, T. J. \& Vale, R. D. Branching Microtubule Nucleation in Xenopus Egg Extracts Mediated by Augmin and TPX2. Cell 152, 768-777 (2013).

10. Petry, S., Pugieux, C., Nedelec, F. J. \& Vale, R. D. Augmin promotes meiotic spindle formation and bipolarity in Xenopus egg extracts. Proc.Natl. Acad. Sci. 108, 14473-14478 (2011).

11. David, A.F., Roudot, P., Legant, W.R., Betzig, E., Danuser, G. \& Gerlich, D.W. Augmin accumulation on long-lived microtubules drives amplification and kinetochore-directed growth. J Cell Biol. (2019). doi:10.1083/jcb.201805044 
bioRxiv preprint doi: https://doi org/10.1101/700419; this version posted July 11, 2019. The copyright holder for this preprint (which was not certified by peer review) is the author/funder, who has granted bioRxiv a license to display the preprint in perpetuity. It is made available under aCC-BY 4.0 International license.

Branched MT nucleation

Tariq et al.,

409

410

411

412

413

414

415

416

417

418

419

420

421

422

423

424

425

426

427

428

429

430

431

432

433

434

435

436

437

438

439

440

441

442

443

444

445

12. Hayward, D., Metz, J., Pellacani, C. \& Wakefield, J. G. Synergy between Multiple Microtubule-Generating Pathways Confers Robustness to Centrosome-Driven Mitotic Spindle Formation. Dev Cell. 28, 81-93 (2014).

13. Ho C.-M., Hotta T., Kong Z., Zeng C. J., Sun J., Lee Y.-R. \& Liu B. Augmin plays a critical role in organizing the spindle and phragmoplast microtubule arrays in Arabidopsis. Plant Cell 23, 2606-2618 (2011).

14. Lawo, S., Bashkurov, M., Mullin, M., Ferreria, M. G., Kittler, R., Habermann, B., Tagliaferro, A., Poser, I., Hutchins, J.R.A., Hegemann, B. Pinchev, D, Buchholz, F, Peters, J.M., Hyman, A.A., Gingras, A.C. \& Pelletier, L. HAUS, the 8-subunit human Augmin complex, regulates centrosome and spindle integrity. Curr. Biol. 19, 816-826 (2009).

15. Hsia, K.C., Wilson-Kubalek, E.M., Dottore, A., Hao, Q., Tsai, K.L., Forth, S., Shimamoto, Y., Milligan, R.A., \& Kapoor, T.M. Reconstitution of the augmin complex provides insights into its architecture and function. Nat Cell Biol. 16, 852-863 (2014).

16. Song, J.G., King, M.R., Zhang, R., Kadzik, R.S., Thawani, A. \& Petry, S. Mechanism of how augmin directly targets the y-tubulin ring complex to microtubules. J Cell Biol. 217, 2417-2428 (2018).

17. Oegema, K., Wiese, C., Martin, O.C., Milligan, R.A., Iwamatsu, A., Mitchison, T.J, \& Zheng, Y. Characterization of Two Related Drosophila y-tubulin Complexes that Differ in Their Ability to Nucleate Microtubules. J Cell Biol. 144, 721-733 (1999).

18. Trokter, M., Mucke, N. \& Surrey, T. Reconstitution of the human cytoplasmic dynein complex. Proc Natl Acad Sci. 109, 20895-20900 (2012).

19. Schlager, M. A., Hoang, H. T., Urnavicius, L., Bullock, S. L. \& Carter, A. P. In vitro reconstitution of a highly processive recombinant human dynein complex. EMBO J. 33, 1855-1868 (2014).

20. Chen, J.W.C., Chen, Z.A., Rogala, K.B., Metz, J., Deane, C.M., Rappsilber, J., \& Wakefield, J.G. Cross-linking mass spectrometry identifies new interfaces of Augmin required to localise the $y$-tubulin ring complex to the mitotic spindle. Biol Open. 6, 654-663 (2017). 
Branched MT nucleation

Tariq et al.,

446

447

448

449

450

451

452

453

454

455

456

457

458

459

460

461

462

463

464

465

466

467

468

469

470

471

472

473

474

475

476

477

478

479

480

481

21. Hallen, M. A., Ho, J., Yankel, C. D. \& Endow, S. A. Fluorescence Recovery Kinetic

Analysis of $\mathrm{y}$-Tubulin Binding to the Mitotic Spindle. Biophys J. 95, 3048-3058 (2008).

22. Chesnel, F., Bazile, F., Pascal, A. \& Kubiak, J. Z. Cyclin B Dissociation from CDK1 Precedes its Degradation Upon MPF Inactivation in Mitotic Extracts of Xenopus laevis Embryos. Cell Cycle 5, 1687-1698 (2006).

23. Barnett, T. The isolation and characterization of Drosophila yolk protein genes. Cell 21, 729-738 (1980).

24. Hughes, J.R., Meireles, A.M., Fisher, K.H., Garcia, A., Antrobus, P.R., Wainman, A., Zitzmann, N., Deane, C., Ohkura, H. \& Wakefield, J.G. A Microtubule Interactome:

Complexes with Roles in Cell Cycle and Mitosis. PLoS Biology 6, (2008).

25. Wainman, A., Buster, D.W., Duncan, T., Metz, J., Ma, A., Sharp, D. \& Wakefield, J.G. A new Augmin subunit, Msd1, demonstrates the importance of mitotic spindle-templated microtubule nucleation in the absence of functioning centrosomes. Genes Dev. 23, 18761881 (2009).

26. Bonne, D., Heusele, C., Simon, C., \& Pantaloni, D. 4', 6-Diamidino-2- phenylindole, a fluorescent probe for tubulin and microtubules. J Cell Biol. 260 2819- 2825 (1985).

27. Goshima, G., Wollman, R., Goodwin, S.S., Zhang, N., Scholey, J.M., Vale, R.D., \& Stuurman, N. Genes Required for Mitotic Spindle Assembly in Drosophila S2 Cells. Science 316, 417-421 (2007).

28. Thawani, A., Stone, H. A., Shaevitz, J. W. \& Petry, S. Spatiotemporal organization of branched microtubule networks. (2019). eLife 8:e43890

29. Verma, V. \& Maresca, T. Direct observation of branching MT nucleation in living animal cells. (2019) BioRXiV doi.org/10.1101/613463

30. Fridy, P.C., Thompson, M.K., Ketaren, N.E. \& Rout, M.P. Engineered high-affinity nanobodies recognizing staphylococcal Protein $A$ and suitable for native isolation of protein complexes. Anal Biochem. 477:92-4 (2015). 


\section{Figure 1}

a

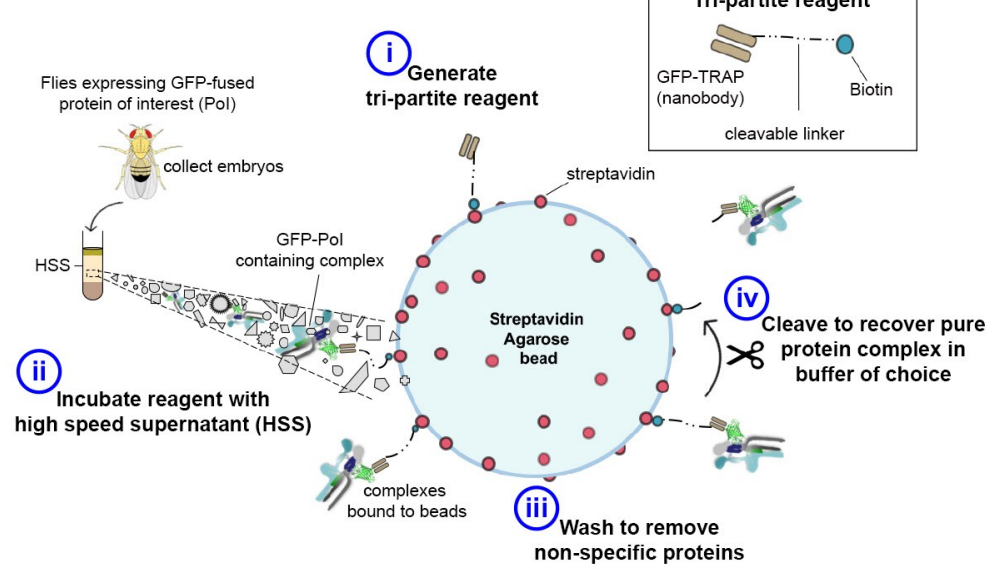

C

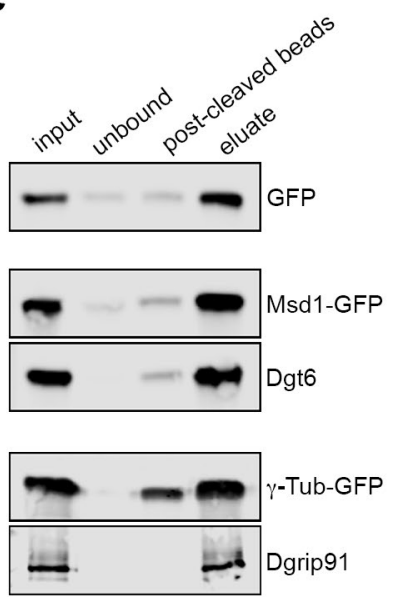

d

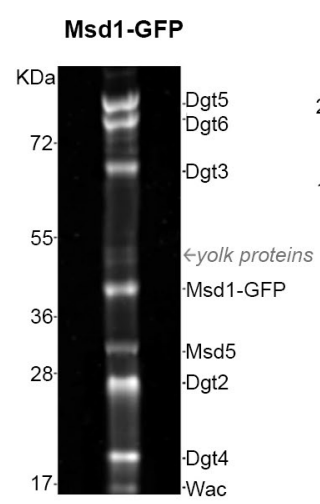

b

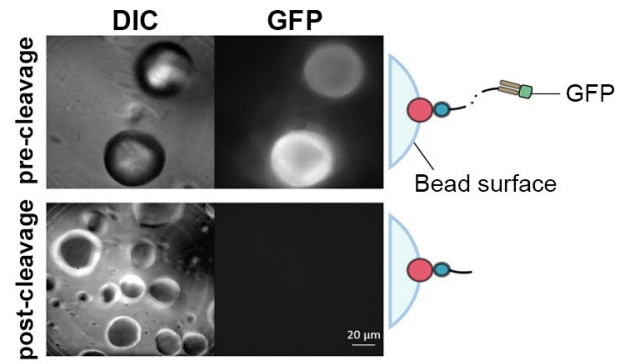

e

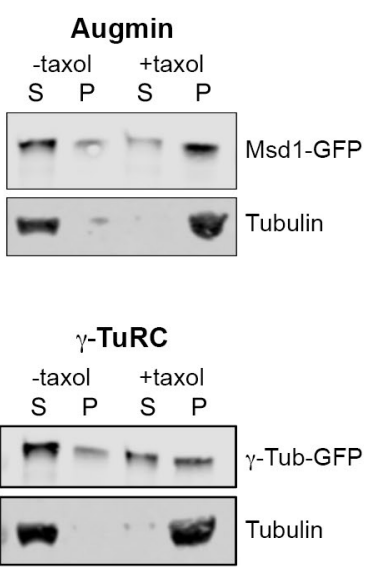

Figure 1 Isolation of functional $\gamma$-TuRC and Augmin using cleavable affinity purification. a. sketch of purification methodology. b. images of GFP-TRAP-Sulfo beads after incubation with GFP, pre- and post-cleavage by 50mM DTT. c. Western blots demonstrating the isolation and cleavage of proteins of interest and interactors. GFP, Msd1-GFP and $\gamma$-Tubulin-GFP, present in embryo extracts (input) are efficiently depleted upon incubation with GFP-TRAP-Sulfo beads (unbound), released in 50mM DTT (post-cleaved beads) and present in the eluate. Dgt6, a subunit of Augmin, co-elutes with Msd1-GFP while Dgrip91, a subunit of $\gamma$-TuRC, co-elutes with $\gamma$-Tubulin-GFP. d. SYPRO-ruby stained gels of postcleaved eluates from control embryos (OrR), or embryos expressing the Augmin subunit Msd1-GFP or $\gamma$-Tubulin-GFP. e. Western blots of in vitro MT co-sedimentation assays using GFP-TRAP-Sulfo isolated complexes. In the absence of taxol (-), Tubulin, pure Augmin (Msd1-GFP) and pure $\gamma$-TuRC ( $\gamma$-TubulinGFP) remain in the supernatant (S). In the presence of taxol (+), Tubulin polymerises and is present in the pellet $(P)$. Augmin and $\gamma$-TuRC co-sediment. 


\section{Figure 2}

a

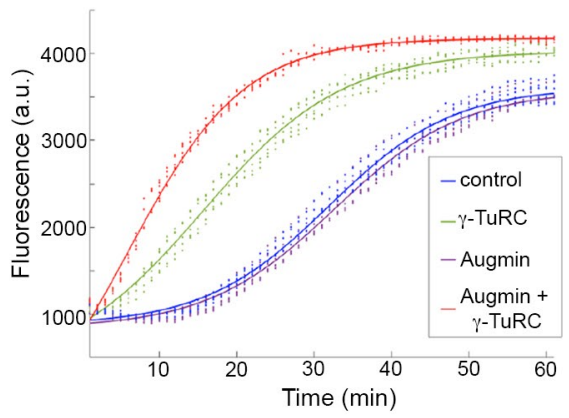

b

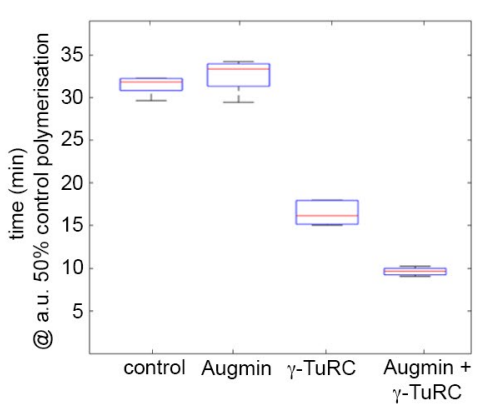

C

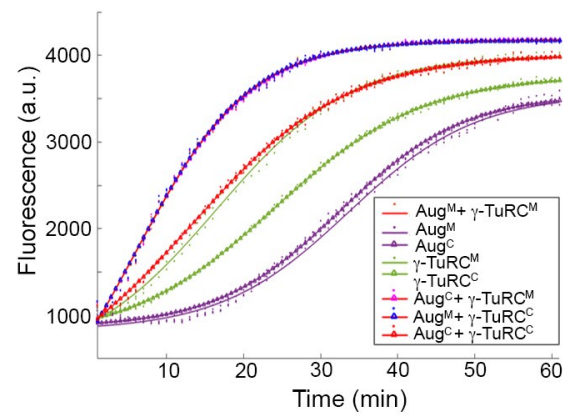

Figure 2 Pure Augmin enhances $\gamma$-TuRC-dependent MT nucleation in a cell cycle dependent manner. a. Tubulin polymerisation assays, where fluorescence is directly related to the amount of Tubulin polymer present. The curves are a sigmoidal fit to six data points (dots); three independent purification experiments, each undertaken in duplicate. b. plot of the x50 in relation to control polymerisation assay, showing the median (red line), interquartile ranges (blue box) and $95 \%$ confidence intervals of the median (notches) for each condition. The differences in the time taken for $50 \%$ polymerisation between all conditions differs significantly at $p=0.001$, except when comparing control to Augmin (ANOVA). c. fluorescent tubulin polymerisation assays undertaken with complexes isolated from MG132-treated (mitotic) or cycling embryos. 
Figure 3

a
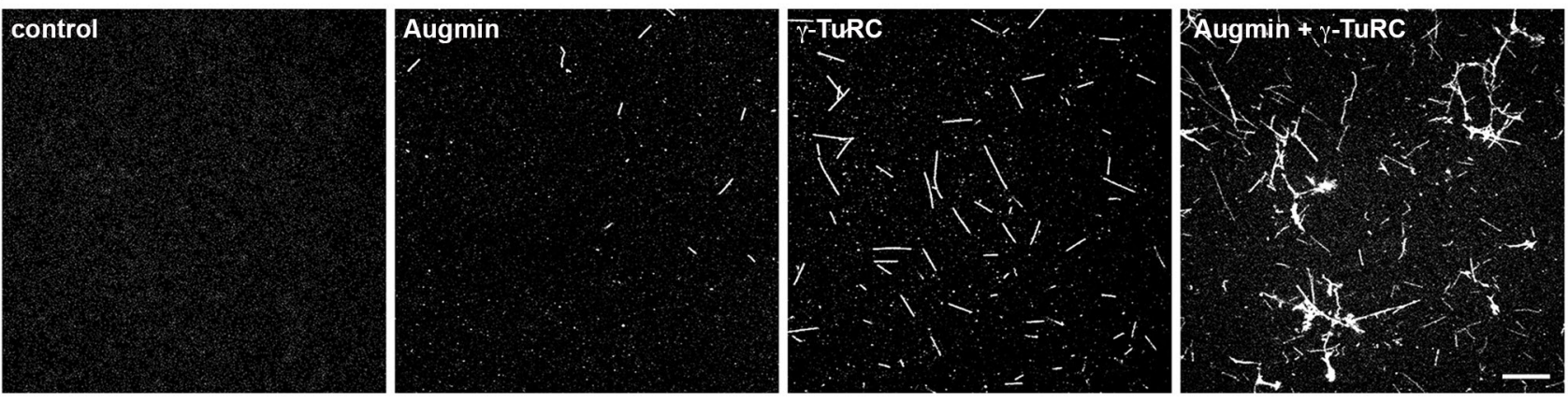

b

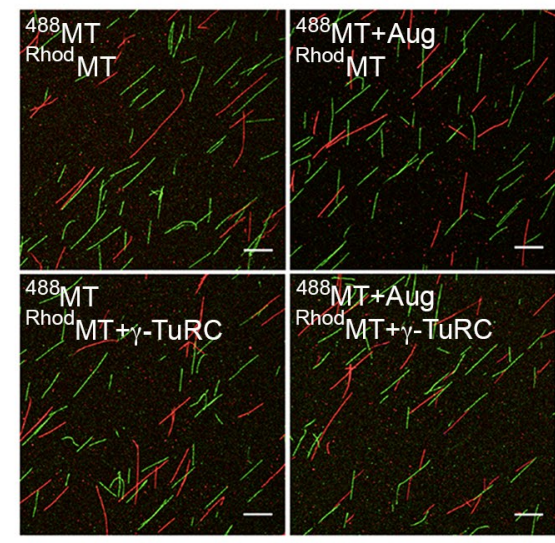

e

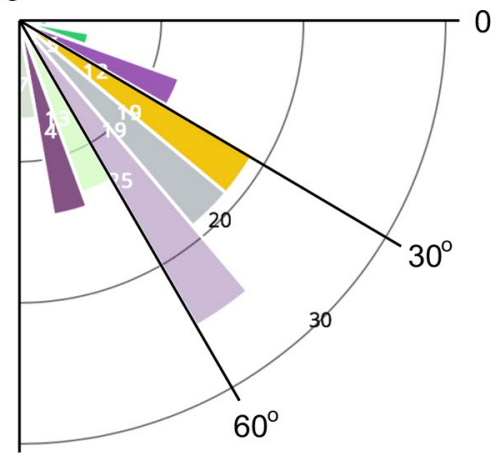

$90^{\circ}$ c

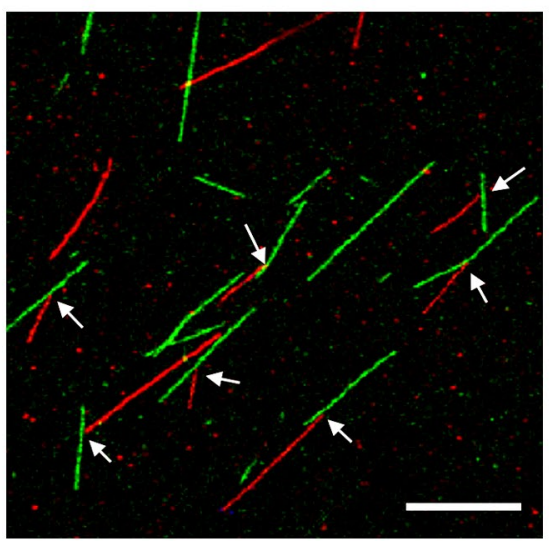

f

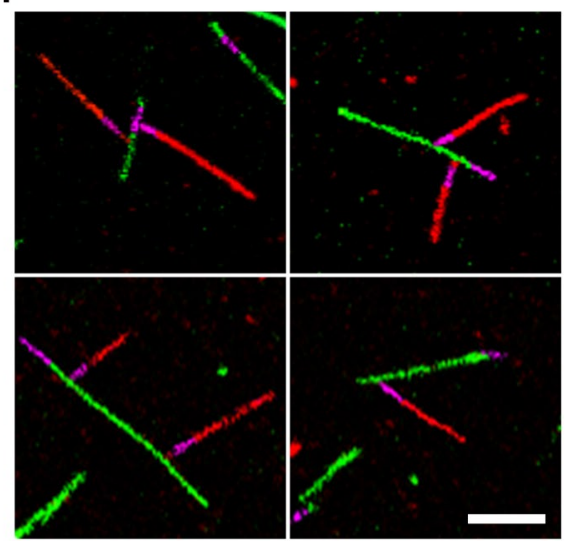

d

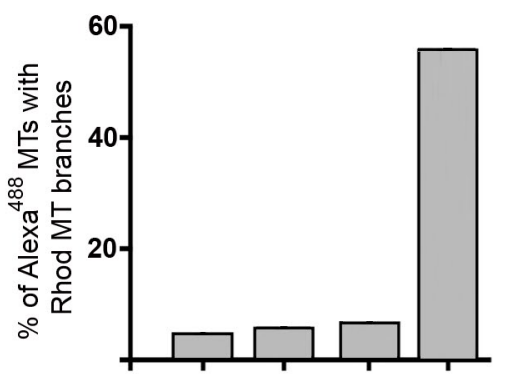

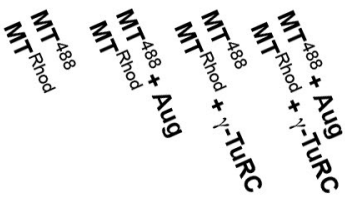

g

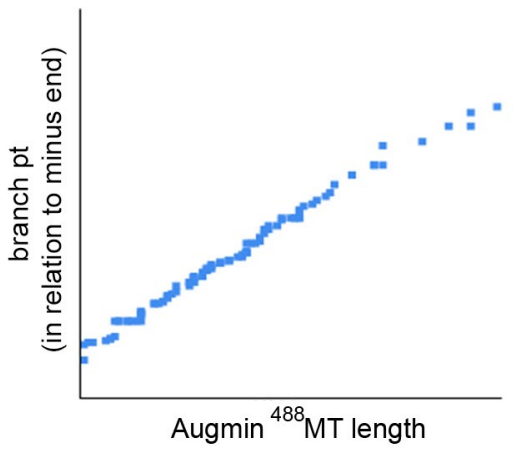

Figure 3 Reconstitution of the MT-Augmin- $\gamma$-TuRC-MT junction. a. confocal images of fixed, fluorescent polymerisation assays at $\mathrm{t}=15$ mins for each condition. $\mathbf{b}$. confocal images of taxol stabilised MTs, formed in the absence or presence of pure Augmin and $\gamma$-TuRC, and co-incubated. Incubation of

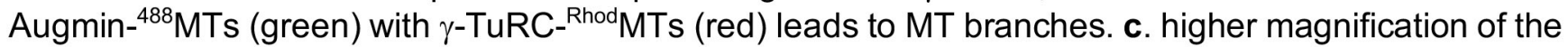
MT-Augmin- $\gamma$-TuRC-MT junctions (arrows). d. histogram of the percentage of ${ }^{488} \mathrm{MTs}$ that possess a

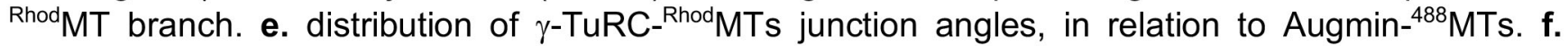
confocal images of junctions, using GMPCPP seeds (purple) to distinguish the MT minus ends. Minus

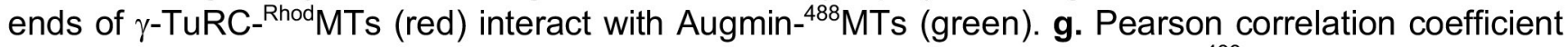
plot demonstrating a strong positive correlation between the length of Augmin- ${ }^{488} \mathrm{MTs}$ and the position

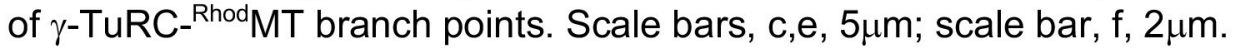

